\title{
Abdominal Skin
}

National Cancer Institute

\section{Source}

National Cancer Institute. Abdominal Skin. NCI Thesaurus. Code C52758.

The skin or integument surrounding the abdomen. 